\title{
Biosensor Chip for Monitoring of Water Pollution as Novel Test Tool in Public Health: Proof of Principle
}

\author{
Nadira Ibrišimović Mehmedinović, Aldina Kesić, Almir Šestan, Aida Crnkić, Mirza Ibrišimović
}

\begin{abstract}
Humans are generally exposed to a variety of pollutions present in the air they breathe, the food they eat or in the water they drink. Some of the most dangerous pollutions are metals and heavy metals. These are naturally occurring substances which are harmless when present in the environment at low levels. However, due to many pollutants such as industry processes or war activities, the heavy metal concentration can exceed the limit of tolerance and become very toxic for the natural environment and living organisms in it, including humans. Unlike organic pollutants, the heavy metals (as ions and as particulate matter) once introduced into the environment cannot be biodegraded and remain there indefinitely. By rainfall these pollutants can be partially transferred from air or soil into the rivers and drinking water sources, where they accumulate in even higher toxic levels. The high concentrations of heavy metals in contaminated natural water reservoirs have an impact on the microbial community composition which resides there. This type of water pollution can cause the changes in life cycles of natural bacterial populations, influencing their metabolic processes and proliferation. The presence of pathogens in water is normally indirectly determined by the testing for "indicator organism" such as coliform bacteria. Coliforms are usually present in larger numbers in contaminated water and at the same time they are indicators of whether other pathogenic bacteria are present, too. In crisis situations, like war or some natural disasters, where trusted sources of drinking water are not available anymore, the military and residents of affected areas are forced to use some alternative water resources that cannot be tested for their microbial or metal contamination properly. Therefore, the existence of some fast test that would detect not only dangerous bacterial pathogens in water, but also the presence of metals and heavy metals as well, would be of great help and importance for the human health. Even though the number of pathogens can be drastically reduced by the boiling of water, the heavy metals are not destroyed by high temperature. Hence the main objective of our work was to optimize the biosensor chip for microbial detection in contaminated water that would serve at the same time as an indicator for the chemical composition of the water,
\end{abstract}

Manuscript received on June 17, 2021.

Revised Manuscript received on June 22, 2021.

Manuscript published on June 30, 2021.

* Correspondence Author

Nadira Ibrišimović Mehmedinović*, Department of Chemistry, Faculty of Natural Sciences and Mathematics, University of Tuzla, Tuzla, Bosnia and Herzegovina. Email: nadira.ibrisimovic@untz.ba

Aldina Kesić, Department of Chemistry, Faculty of Natural Sciences and Mathematics, University of Tuzla, Tuzla, Bosnia and Herzegovina. Email: aldina.kesic@untz.ba

Almir Šestan, Department of Chemistry, Faculty of Natural Sciences and Mathematics, University of Tuzla, Tuzla, Bosnia and Herzegovina. Email: almir.sestan@untz.ba

Aida Crnkić, Department of Chemistry, Faculty of Natural Sciences and Mathematics, University of Tuzla, Tuzla, Bosnia and Herzegovina. Email: aida.crnkic@untz.ba

Mirza Ibrišimović, Gynecological polyclinic "Korak do života”, Tuzla, Bosnia and Herzegovina and Sarajevo Medical School, University Sarajevo School of Science and Technology, Sarajevo, Bosnia and Herzegovina. Email: ibrisimovic2001@yahoo.com

(c) The Authors. Published by Blue Eyes Intelligence Engineering and Sciences Publication (BEIESP). This is an open access article under the CC BY-NC-ND license (http://creativecommons.org/licenses/by-nc-nd/4.0/) such as presence of metals and heavy metals, with potential to be used as a novel test tool in public health.

Keywords: Biosensor, Heavy Metals, Microbes, Water Pollutants.

\section{INTRODUCTION}

$\mathrm{R}$ quality include both the total number of microorganisms and the presence of pathogens. Even non-pathogens, if present in large enough numbers, can cause deterioration of food products and distaste in water (1). Coliform bacteria can serve as indicators of fecal contamination (2). Coliforms are defined as "Gram-negative aerobic or facultative anaerobes, nonspore-forming, rod shaped bacteria that ferment lactose with acid and gas production. The coliform group includes the genera of Esherichia, Enterobacter, Klebsiella and Citrobacter (3).

Many metals serve as cofactors for enzymes which are excreted by bacteria, e.g. coliforms, which are commonly present in polluted water. Based on the fact that the biosensor technology that was used in this study is capable of detecting microbial enzymes as described in some our previous studies (4-7), manifestation and intensity of the signal was changing in dependence on which metal/heavy metal is present in a test sample. It was shown that presence of some metals in water, like zinc, manganese or calcium which are building up the active site of some microbial enzymes, can increase the sensitivity and functionality of the biosensor. On the other hand, some heavy metals like mercury can inhibit the metabolic activity of microorganisms and lower down the biosensor's detection signal. Water contamination can include some radioactive elements like cesium and polonium which are generally released from explosives, and which are found in natural waters worldwide (8).

Heavy metals are found naturally in the earth and are not treating to the environment if present in low trace. However, if their concentrations exceed the limit of tolerance, they can become very toxic to the natural environment and living organisms in it, including humans (9). Metals can be introduced in aquatic systems by weathering of soils or from different human factors including the war activities, the mining or some other industrial processes.

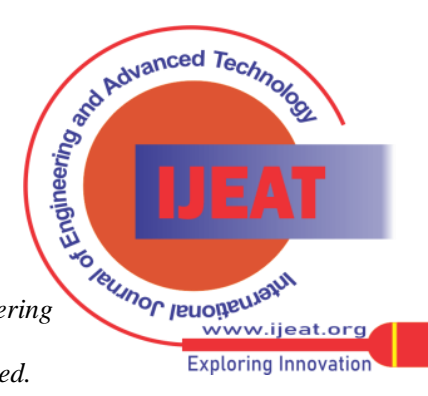


Unlike organic pollutants, the heavy metals once introduced into the environment cannot be biodegraded and remain there indefinitely $(10,11)$. Methods for remediation of heavy metals from contaminated environment are very complicated and time demanding, including physical removal, bioleaching and detoxification (11). In water, when the $\mathrm{pH}$ decreases, metal solubility and toxicity will increase and the metal particles can become more mobile. Since the habitats for aquatic organisms are usually the water or sediments, the captured heavy metals can accumulate in tissues of species residing there, including fish and macrophytes. Besides water, the heavy metals like zinc, cadmium, mercury, and chromium can pollute the air and soil, and contaminate the living forms present there. The sensitivity of individuals of a particular aquatic species to heavy metals may be influenced by factors such as age, sex, or size. The accumulation of heavy metals in plant or animal tissues can influence their life cycle and reproduction and through the food chain endanger the human health $(12,13)$.

For example, the concentration of metals in invertebrates is conversely related to their body mass. It is expected that the embryonic and larva stage of fish is the most sensitive to this type of pollution (12). Some of the water bacteria are capable of converting mercury to the toxic methyl mercury that accumulate in fish and can cause serious health problems for the human body (13). A long-term exposure to heavy metals can cause an acute or chronic damage of nervous system, renal dysfunction, lung disease and lately there is an increasing number of reports about stimulated effect of heavy metals on some types of human cancer (15-17).

The metabolic features of microorganisms (primarily bacteria), which were closely investigated in course of our study, were used to optimize the biosensor matrix, the biosensor's setup, and the type of color change that is displayed as an optical detection signal. This biosensor technology enabled identification of the aquatic ecosystems in Bosnia and Herzegovina containing toxic amounts of heavy metals, which can endanger living organisms habiting there and human health as well. The study was proof of principal of optimized patented biotechnology chip (7) as a fast test for presence of microbiological and chemical contaminants in water.

\section{MATERIALS AND METHODS}

\section{A. Collection of Water Samples}

For our work we used the water samples of the largest rivers in Bosnia and Hercegovina: Bosna, Drina, Sava and Neretva. From all rivers the samples were taken in urban areas with approximately the same number of inhabitants per $\mathrm{m} 2$. After the water samples were taken in $1000 \mathrm{~mL}$ plastic bottles, they were analyze for their chemical and microbial status. First parameters being analyzed were: electrical conductivity, $\mathrm{pH}$ and temperature.

\section{B. Determination of Heavy Metals Amount Using AES}

The collected water samples were analyzed in laboratory for trace metals by Atomic Emission Spectrometer (AES). The following heavy metals were analyzed: zinc ( $\mathrm{Zn})$, lead $(\mathrm{Pb})$, chromium $(\mathrm{Cr})$, iron $(\mathrm{Fe})$, manganese $(\mathrm{Mn})$, barium (Ba), tin (Tin), thallium (Tl) and selenium (Se). The detection of traced metals was performed by AAS. It is known that heavy metals regularly form complexes with organic constituents. Therefore, it was important to digest the organic components by using a strong acid that would in contrary cause interference and an unreliable measuring value. Interfering were removed by using $37 \%$ hydrochloric acid ( $\mathrm{HCl}$ )- end concentration of $1 \%$ in water samples.

\section{Microbiological Analysis of Water Samples and Recognition of Indicators for Microbial Water Quality}

For the identifications of microorganisms we used ÖNOZ and Aero Pseudo Selective Agar (Himedia), and other conventional microbiological methods (MacConkey agar, Manitol salt agar from Merck).

\section{Quantitative Monitoring of Microbial Enzymatic Activity}

For testing of enzymatic activity we determined Leucine aminopeptidase (LAP) which is a common virulence factor of coliform bacteria such as Enterobacter spp, Esherichia spp. and Pseudomonas spp. A test samples was examined for the exopeptidase LAP activity that selectively releases $\mathrm{N}$-terminal amino acid residues from polypeptides and proteins. Since the temperature plays very important role in activation of the enzyme, the enzyme dilutions must be incubated for 15 minutes at $37^{\circ} \mathrm{C}$. A calibration line can be generated by means of increasing LAP activities. Therefore a stock of LAP with a specific activity of $10 \mathrm{U} / \mathrm{mg}$ must be prepared. The used LAP dilutions should be in the range of 10 to $1000 \mathrm{mU} / \mathrm{mg}$. The reagents which will be used are:

a) $60 \mathrm{mM}$ Phosphate Buffer, $\mathrm{pH} 7.2$ at $37^{\circ} \mathrm{C}$ (Prepare 100 $\mathrm{ml}$ in deionized water using potassium phosphate, monobasic, anhydrous. Adjust to $\mathrm{pH} 7.2$ at $37{ }^{\circ} \mathrm{C}$ with $1 \mathrm{M}$ $\mathrm{KOH}$.).

b) $1.66 \mathrm{mM}$ L-Leucine p-Nitroanilide Solution (L-Leu_NA) (Prepare $30 \mathrm{ml}$ in Reagent a using L-leucine p-nitroanilide hydrochloride. Prepare fresh!).

c) $10 \mathrm{mM}$ TrisHCl Buffer with $1 \mathrm{mM} \mathrm{MgCl2,} \mathrm{pH} 8.0$ at $37{ }^{\circ} \mathrm{C}$ (Activation Buffer) (Prepare $20 \mathrm{ml}$ deionized water using Trizma Base. Adjust to $\mathrm{pH} 8.0$ at $37^{\circ} \mathrm{C}$ with $1 \mathrm{M} \mathrm{HCl}$ and then add $\mathrm{MgCl} 2$ x 6H2O).

d) Leucine Aminopeptidase Enzyme Solution, Non-Activated (Enz-Non Act) (Immediately before use, prepare a solution containing 0.3 unit $/ \mathrm{ml}$ of leucine aminopeptidase in cold deionized water).

e) Leucine Aminopeptidase Enzyme Solution, Acivated (Enz-Act); (Immediately before use, prepare a solution containing $0.1 \mathrm{U} / \mathrm{ml}$ of leucine aminopeptidase in cold Reagent c. Incubate at $37^{\circ} \mathrm{C}$ for 15 minutes to activate.

\section{E. Development of the Polymer-Based Biosensor Chip}

The presented biosensor setup consists of a reflective layer made up of e.g. Ni-Cr alloy which is covered with a polymer layer (substrate). The polymer layer is normally made up of PLGA (poly lactic-co-glycolic acid) dissolved in ethyl acetate containing varying amounts of desmodur.

Desmodur serves as a linker of the PLGA molecules influencing the viscosity and composition of the polymer, which can be additionally doped with various compounds mediating specific effects.

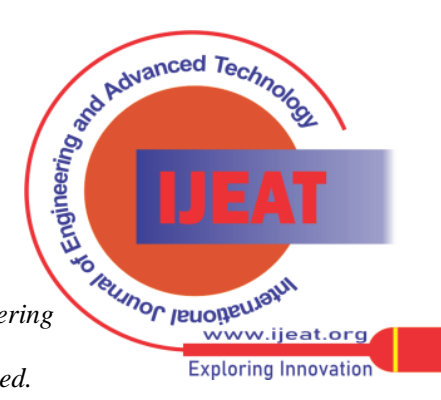


PLGA was approved in the year 2000 by the FDA (Food and Drug Administration) for in vivo use and applications in drug targeting.

When specific lytic enzymes such as those secreted by bacteria come into contact with the polymer layer (specific substrate), the polymer is topically degraded, leading to a color change due to altered refraction of visible light. The biosensor specifically identifies secreted lytic enzymes and therefore offers the possibility of detecting bacterial metabolic activity even in absence of the causative pathogen in the specimen analyzed. Microbes in total count of 10000 $\mathrm{CFU} / \mathrm{ml}$ in liquid, overnight culture, were incubated on the biosensor for different incubation times, and presence of metabolic activity of the microbes was detected due to color change of the biosensor.

\section{RESULTS}

\section{A. In Situ Chemical Analysis of Water Samples and Determination of Heavy Metals Amount Using AES}

All used water samples were analyzed with Hanna HI-9829 Multiparameter pH/ISE/EC/DO/Turbidity. Results of in situ measurement are listed in tables 1 and 2. In situ measurement indicated existence of differences in analyzed parameters for all river samples, showing especially high values for water samples from river Bosna.

Elevated levels of TDS for river Bosnia can be connected to the fact that this river and its tributaries are passing through places with heavy industrial activities, which are main cause for environmental pollution.

Measured concentrations of heavy metals are listed in table 3 . As we can see in table 3 the highest values in heavy metal concentration, from all nine heavy metals being analyzed, showed iron and strontium. The concentration of iron in river Sava was from $0,126 \mathrm{mg} / \mathrm{mL}$ and for strontium in concentration from $0,167 \mathrm{mg} / \mathrm{mL}$.

Table 1. In situ measurements.

\begin{tabular}{|c|c|c|c|c|c|c|}
\hline River & $\begin{array}{c}\text { Temp. } \\
{\left[{ }^{\circ} \mathbf{C}\right]}\end{array}$ & $\begin{array}{c}\mathbf{m V} \\
\mathbf{[ p H}]\end{array}$ & $\begin{array}{c}\text { ORP } \\
{[\mathbf{m V} \mathbf{]}}\end{array}$ & $\begin{array}{c}\mathbf{E C} \\
{[\boldsymbol{\mu} \mathbf{S} / \mathbf{c m}]}\end{array}$ & $\begin{array}{c}\mathbf{E C} \\
\mathbf{A b s} . \\
{[\boldsymbol{\mu S} / \mathbf{c m}]}\end{array}$ \\
\hline Bosna & 13,56 & 6,51 & 5,8 & 151,2 & 412 & 401 \\
\hline Drina & 13,45 & 7,64 & $-56,6$ & 140,2 & 209 & 203 \\
\hline Sava & 13,90 & 7,82 & $-66,2$ & 128,5 & 218 & 214 \\
\hline Neretva & 9,33 & 7,66 & $-43,1$ & 182,9 & 283 & 199 \\
\hline
\end{tabular}

ORP-oxidation reduction potential

EC- electrical conductivity

Table 2. Results of chemical analysis of water samples.

\begin{tabular}{|c|c|c|c|c|c|}
\hline River & $\begin{array}{c}\text { RES } \\
{[\mathbf{O h m - c m ]}}\end{array}$ & $\begin{array}{c}\text { TDS } \\
\text { [ppm] }\end{array}$ & $\begin{array}{c}\text { Sal. } \\
\text { [psu] }\end{array}$ & $\begin{array}{c}\text { D.O. } \\
{[\mathbf{\%}]}\end{array}$ & $\begin{array}{c}\text { D.O. } \\
{[\mathbf{p p m}]}\end{array}$ \\
\hline Bosna & 2427 & 206 & 0,20 & 72,9 & 6,04 \\
\hline Drina & 4785 & 104 & $9,82 \mathrm{E}-02$ & 72,7 & 6,04 \\
\hline Sava & 4587 & 109 & 0,10 & 67,2 & 5,54 \\
\hline Neretva & 3500 & 141 & 0,14 & 91,4 & 10,37 \\
\hline
\end{tabular}

TDS- Total dissolved solids

D.O. - Dissolved Oxygen

Table 3. Concentrations of heavy metals in $\mathrm{mg} / \mathrm{mL}$ from water samples from rivers Bosna, Drina, Sava, and

Neretva.

\begin{tabular}{|c|c|c|c|c|c|}
\hline \multicolumn{7}{|c|}{ Heavy metals concentration (mg/mL) } \\
\hline River & Ba & Cr & Fe & Mn & Pb \\
\hline Bosna & 0,008 & 0,004 & 0,087 & 0,029 & 0 \\
\hline Drina & 0,002 & 0,006 & 0,085 & 0,033 & 0,005 \\
\hline Sava & 0,005 & 0,004 & 0,126 & 0,022 & 0,006 \\
\hline Neretva & 0,001 & 0,001 & 0,000 & 0,003 & 0,000 \\
\hline
\end{tabular}

Retrieval Number: 100.1/ijeat.E28430610521

DOI:10.35940/ijeat.E2843.0610521

Journal Website: www.ijeat.org

\begin{tabular}{|c|c|c|c|c|}
\hline \multicolumn{5}{|c|}{ Heavy metals concentration $(\mathbf{m g} / \mathbf{m L})$} \\
\hline River & Se & Sn & Sr & Tl \\
\hline Bosna & 0,032 & 0,035 & 0,110 & 0,037 \\
\hline Drina & 0,034 & 0,038 & 0,085 & 0,024 \\
\hline Sava & 0,023 & 0,032 & 0,134 & 0,015 \\
\hline Neretva & 0,036 & 0,036 & 0,167 & 0,045 \\
\hline
\end{tabular}

\section{B. Identification of Microorganisms in Water Samples}

Using conventional microbiological identification methods, from tested water samples it was possible to identify the following microorganisms as habitants in rivers Bosna, Drina, Sava and Neretva: Enterobacter spp., Esherichia spp. ,Pseudomonas spp. and Proteus spp. Enterobacter spp., Esherichia spp and Pseudomonas spp. were found in every tested water sample.

C. Monitoring of Microbial Metabolic Activity by Leucine Aminopeptidase (LAP) Detection in Water Samples

For monitoring of microbial growth and metabolic activity testing, we used isolated strains of Enterobacter spp. and Esherichia spp., which were inoculated in tryptic soy broth for 24 hours at $37^{\circ} \mathrm{C}$ and their metabolic activity was measured after different incubation times (after 0h, 16h, 24h, $32 \mathrm{~h}$ and $48 \mathrm{~h}$ ). Since the iron and strontium as representatives of heavy metals were the most present in tested water samples, they were chosen as substrates for addition to Enterobacter spp., Esherichia spp. and Pseudomonas spp. growing cultures, after which LAP activity was detected.

LAP serves as virulent factor for these microbes and levels of its secretion were not constant in in vitro conditions, after various incubation times (figures 1-3). In order to monitor the impact of heavy metals, we used heavy metals Fe and $\mathrm{Sr}$ in two concentrations, as follows: $\mathrm{Fe} 1=0.085 \mathrm{mg} / \mathrm{L}$; $\mathrm{Fe} 2=$ $0.126 \mathrm{mg} / \mathrm{L} ; \mathrm{Sr} 1=0.085 \mathrm{mg} / \mathrm{L}$ and Sr2 $=0.167 \mathrm{mg} / \mathrm{L}$. As we can see from the figures $1-4$, the presence of heavy metals had a stimulating effect on the virulence of microorganisms, and elevated excretion of LAP could be observed.

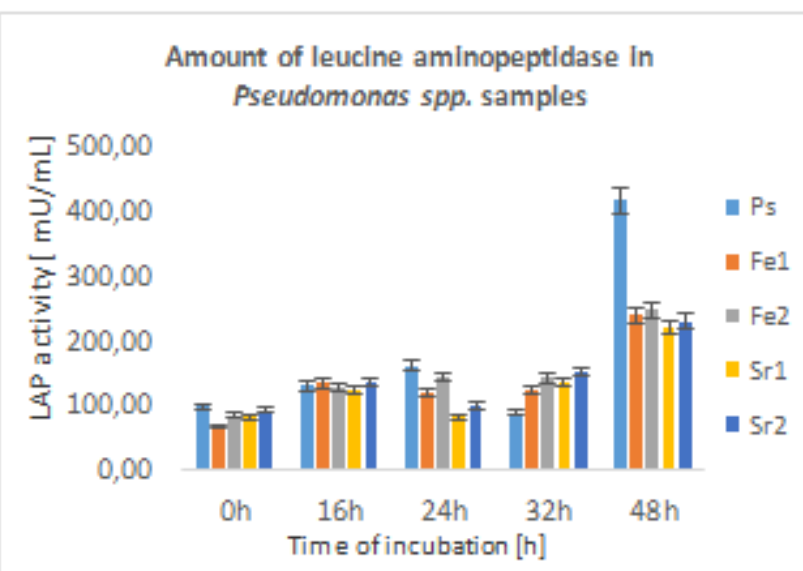

Figure 1. Influence of heavy metals iron (Fe) and strontium (Sr) in samples of Pseudomonas spp.

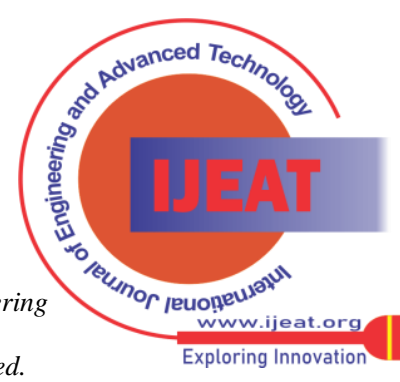




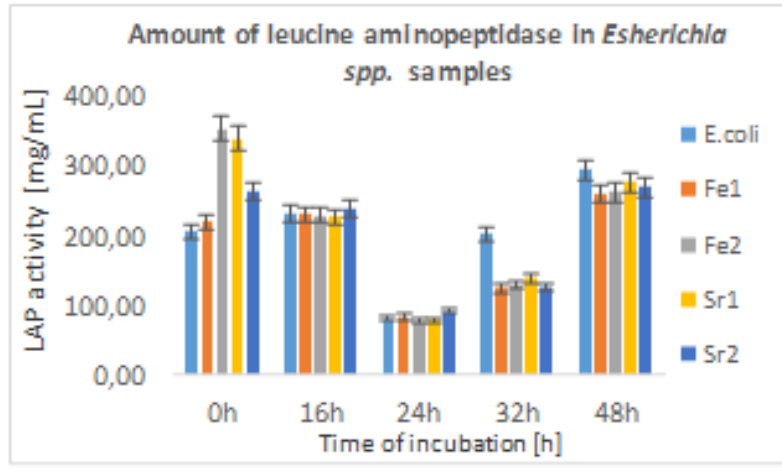

Figure 2. Influence of heavy metals iron (Fe) and strontium (Sr =in samples of Esherichia spp.

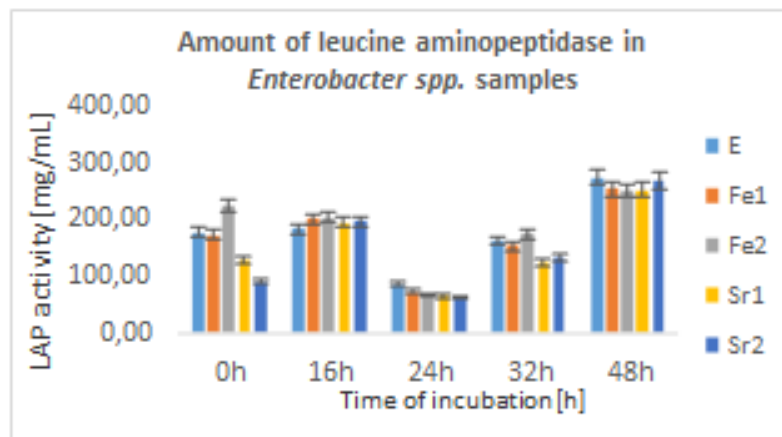

Figure 3. Influence of heavy metals iron Fe and strontium Sr in samples of Enterobacter spp.

D. Proof of principle for biosensor chip detecting heavy metal pollutants and microbial contaminants in water ecosystems

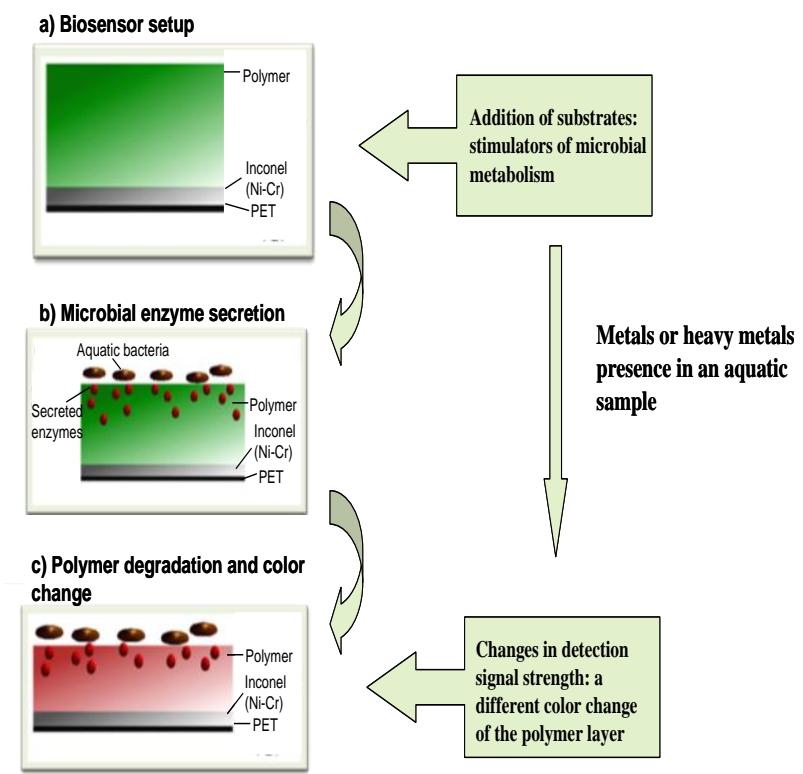

Figure 4. A polymer-based, optical biosensor chip for detection of microbial and chemical contamination in an aquatic sample and its mechanism of action.

When lytic enzymes (e.g. secreted by bacteria) come into contact with the polymer layer of biosensor, the polymer will be degraded resulting in a topical color change of the biochip, for example from green to red (figure 4).

Some of the additives act as a carbon and/or energy source for specific microorganisms and provide the nutritional environment triggering the release of lytic enzymes, thus improving the efficacy of detection.

For functionality test we used biosensors with PLGA concentration in range between 18-23\% PLGA with 1\% Desmodur and substrate glucose, tryptone and inorganic salts. All the biosensors were incubate by $37^{\circ} \mathrm{C}$ for $4 \mathrm{~h}$ and 24h.

Proof of principle of biosensor chip for monitoring of water pollution are carried out with microorganisms and water samples. (Ps- Pseudomonas spp., Ec- Esherichia spp., En- Enterobacter spp.)

The color changes shown in figure 5 and figure 6 are result of enzymatic degradation of the biomimetic polymer layer by lytic enzymes. The degradation is highly selective and clearly visible with naked eyes. The signal intensity correlates with increasing incubation time.

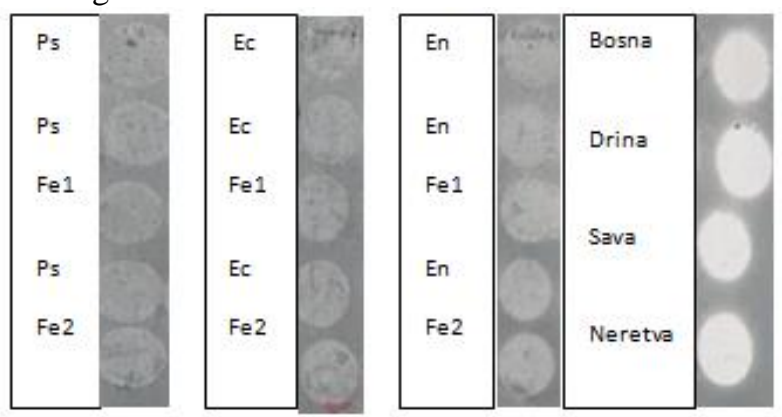

Figure 5. Signal intensity after incubation for $\mathbf{4 h}$ and temperature at $37^{\circ} \mathrm{C}$.

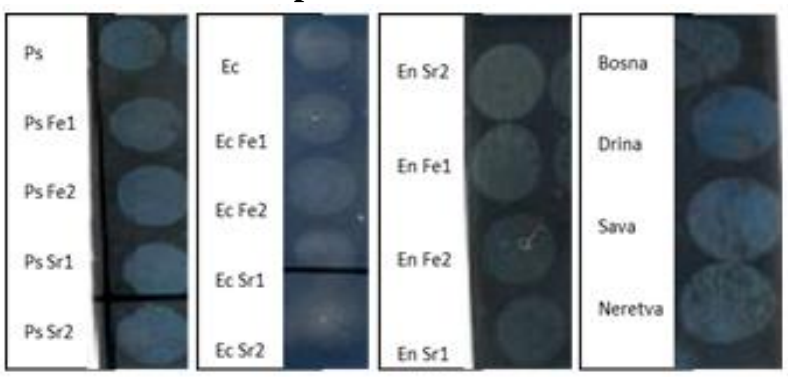

Figure 6. Signal intensity after incubation for $24 \mathrm{~h}$ and temperature at $37^{\circ} \mathrm{C}$.

\section{CONCLUSIONS}

Coliform bacteria are routinely used as an indicator of the microbiological quality of water. They are present in the environment and feces of all warm-blooded animals and humans.

The coliforms are unlikely to cause illness, but their presence in water reservoirs indicates that disease-causing organisms (pathogens) could be in the water system. Since the testing of water samples of different origin, for all possible pathogens is complex, time-consuming, and expensive, this problem is solved by testing for coliforms only, applying simple and inexpensive methodology, such as biosensor chip technology presented in our study. In our study we were also able to show that here presented patented biosensor technology can be optimized for detection of bacterial contamination in water and joined with heavy metal contamination.

Published By:

Blue Eyes Intelligence Engineering and Sciences Publication

(C) Copyright: All rights reserved.

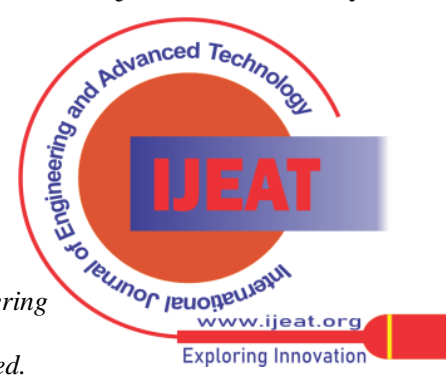


Experiments with iron and strontium for strains Esherichia spp., Pseudomonas spp. and Enterobacter spp. showed that signal intensity on surface of biosensor is increasing due to addition of heavy metals as substrates, in comparison to bacteria alone. This means that presented biosensor chip can be used as dual detecting system for detection of bacteria, parallel with heavy metals, as commonly present pollutants in water ecosystems, and be used as a novel testing tool in protection of public health.

The water samples of the rivers Bosna, Drina, Sava and Neretva showed a clearly visible signal on the surface of the used biosensors that is visible to the naked eye, and based on these results we can conclude that the optimized design of biosensors can detect water pollution in the field in a very short time. The population of risk areas would be able to identify non-drinking water, because its consumption could be harmful to their health.

Since the optimized biosensor can detect metals and heavy metals in all types of accumulated water (groundwater, rivers, lakes, drinking water reservoirs, etc.), it can also be used as a rapid detection method for industrial wastewater, which generally contains a high level of heavy metal.

Due to the fact that most of the aquatic ecosystems we examined are geographically related to other aquatic systems (rivers) in Europe, the obtained data on chemical contamination and its impact on aquatic flora and fauna, including human health, is very important scientific contribution to European water systems as well.

\section{AKNOWLEDGMENT}

This study was financially supported by Federal Ministry of Education and Science, Federation of Bosnia and Herzegovina.

\section{REFERENCES}

1. Majumdar, A., Pradhan, N., Sadasivan, J., Acharya, A., Ojha, N., Babu, S., \& Bose, S. (2018). Food degradation and foodborne diseases: A microbial approach. In Microbial contamination and food degradation (pp. 109-148). Academic Press.

2. Khan, F. M., \& Gupta, R. (2020, January). Escherichia coli (E. coli) as an Indicator of Fecal Contamination in Groundwater: A Review. In International Conference on Sustainable Development of Water and Environment (pp. 225-235). Springer, Cham.

3. Goodfellow, M., Kämpfer, P., Busse, H. J., Trujillo, M. E., Suzuki, K. I., Ludwig, W., \& Whitman, W. B. (Eds.). (2012). Bergey's manual ${ }^{\circledR}$ of systematic bacteriology: Volume five the actinobacteria, part a (pp. 171-206). Springer New York.

4. Ibrišimović, N., Ibrišimović, M., Barth, M., \& Bohrn, U. (2010). Biomimetic PLGA sensor: proof of principle and application. Monatshefte für Chemie-Chemical Monthly, 141(1), 125-130.

5. Ibrišimović, N., Barth, M., Bohrn, U., Ibrišimović, M., \& Pittner, F. (2009). Biomimetic sensor chip monitoring real-time food degradation: correlating chemical deterioration with microbiological status. Monatshefte für Chemie-Chemical Monthly, 140(8), 941-945.

6. Pittner, F., Bauer, M., Bauer, G., Domnick, R., \& Ibrisimovic, N. (2011). U.S. Patent Application No. 12/747,835.

7. Ibrisimovic, N., Ibrisimovic, M., Barth, M., Bohrn, U., \& Pittner, F. (2009). Device comprising a polymer layer and a reflecting layer.

8. Sangvanich, T., Sukwarotwat, V., Wiacek, R. J., Grudzien, R. M., Fryxell, G. E., Addleman, R. S., ... \& Yantasee, W. (2010). Selective capture of cesium and thallium from natural waters and simulated wastes with copper ferrocyanide functionalized mesoporous silica. Journal of hazardous materials, 182(1-3), 225-231.

9. Mudgal, V., Madaan, N., Mudgal, A., Singh, R. B., \& Mishra, S. (2010). Effect of toxic metals on human health. The Open Nutraceuticals Journal, 3(1).

10. Masindi, V., \& Muedi, K. L. (2018). Environmental contamination by heavy metals. Heavy metals, 10, 115-132.

11. RoyChowdhury, A., Datta, R., \& Sarkar, D. (2018). Heavy metal pollution and remediation. In Green chemistry (pp. 359-373).
Elsevier.

12. Sfakianakis, D. G., Renieri, E., Kentouri, M., \& Tsatsakis, A. M. (2015). Effect of heavy metals on fish larvae deformities: a review. Environmental research, 137, 246-255.

13. Zeitoun, M. M., \& Mehana, E. E. (2014). Impact of water pollution with heavy metals on fish health: overview and updates. Global Veterinaria, 12(2), 219-231.

14. De, J., Ramaiah, N., \& Vardanyan, L. (2008). Detoxification of toxic heavy metals by marine bacteria highly resistant to mercury. Marine Biotechnology, 10(4), 471-477.

15. Matés, J. M., Segura, J. A., Alonso, F. J., \& Márquez, J. (2010). Roles of dioxins and heavy metals in cancer and neurological diseases using ROS-mediated mechanisms. Free Radical Biology and Medicine, 49(9), 1328-1341.

16. Romaniuk, A., Lyndin, M., Sikora, V., Lyndina, Y., Romaniuk, S., \& Sikora, K. (2017). Heavy metals effect on breast cancer progression. Journal of Occupational Medicine and Toxicology, 12(1), 1-9.

17. Vigneri, R., Malandrino, P., Giani, F., Russo, M., \& Vigneri, P. (2017). Heavy metals in the volcanic environment and thyroid cancer. Molecular and cellular endocrinology, 457, 73-80.

\section{AUTHORS PROFILE}

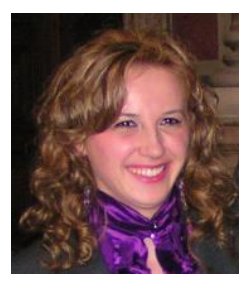

Nadira Ibrišimović Mehmedinović, is associate professor at Department of Chemistry, Faculty of Natural Sciences and Mathematics, University of Tuzla, Tuzla, Bosnia and Herzegovina. Nadira Ibrišimović Mehmedinović is author of 23 scientific publications and four books, including two patents: 1. Ibrišimović, N., Pittner, F., Ibrišimović, M., Barth, M., Bohrn, U. (2009). Device comprising a polymer layer and a reflecting layer. EP2278300 A1, Europe and USA.

2. Fritz Pittner, Maria Bauer, Georg Bauer, Ralph Domnick, Nadira Ibrisimovic. „Device comprising two reflecting layers and a polymer layer for analyzing the age and/or quality of natural products“, U7098/DB, PCT/EP2007/063895 (2008). Selected publications:

1. Perspective potential of polymer-based biosensor chips in food industry and clinical diagnostics, N. Ibrišimović Mehmedinović, M. Ibrišimović, A. Kesić, S. Marić.. Book: Biodegradable Polymers: Recent Developments and New Perspectives. May 2017 DOI: 10.5599/obp.14.9.

2. Original paper- Chromatographic isolation of superoxide dismutase enzyme from Calendula officinalis and its anticancer activity in vitro, $\mathrm{N}$. Ibrišimović Mehmedinović, M. Ibrišimović, J. Dedić, European Journal of Scientific Research, Volume 144 Issue 2, 2017.

3. Original paper- Effects of various metal and drug agents on excretion of enzyme aspartyl proteinase in Candida albicans and its role in human physiological processes, M. Ibrišimović, N. Ibrišimović Mehmedinović, J. Dedić, A. Kesić, S. Marić, A. Šestan, CMBEBIH 2017, IFMBE Proceedings of the International Conference on Medical and Biological Engineering 2017, Volume 62, 2017, Springer Singapore, DOI 10.1007/978-981-10-4166-2_110, ISBN: 978-981-10-4165-5.

4. Original paper- The Bioavailability of Manganese in the Marigold ( Calendula officinalis L.) grown on alkaline soil, Z. Hodžić, M. Saletović, A. Crnkić, A. Kesić, N. Ibrišimović Mehmedinović, A. Šestan, American Journal of Applied Chemistry, ISSN:2330-8753 , Vol.6 Issue2, May-June 2016, pp.141-145.

5. Original paper- Distribution of Heavy Metals (Cr, Cu, Ni, Pb and $\mathrm{Zn}$ ) in the sediment of some tributaries and the part of the river Spreča flow presented by the Krigging geostatistical method, A. Šestan, E. Hadžimustafić, I. Šestan, A. Kesić, N. Ibrišimović Mehmedinović, International Journal of Research Methodology, Human Journals, Vol.1, Issue 4, 2019.

6. Original paper- Insulin Acts as Stimulatory Agent in Diabetes-Related Escherichia Coli Pathogenesis, Madacki-Todorović K., Eminović I., Ibrišimović Mehmedinović N., Ibrišimović M., Internationa Journal of Diabetes and Clinical Research. Issue 4, Volume 5, December 2018.

7. Original paper- Optical activity, total phenolic content and color intensity of nectarian honey and honeydew A. Kesić, S. Ćelan, N. Ibrišimović Mehmedinović, A. Šestan. European Journal of Food Science and Technology. Vol.8, No.1, pp.12-33, February 2020. Published by ECRTD UK. Print ISSN: 2056-5798, Online ISSN: 2056-5801.

Published By:

Blue Eyes Intelligence Engineering and Sciences Publication 


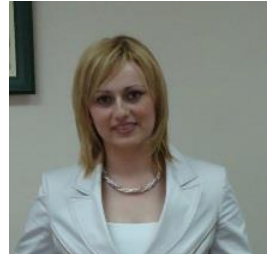

Aldina Kesić, is associate professor at Faculty of Natural Science and Mathematics, at University in Tuzla, Bosnia and Herzegovina. Aldina Kesić is author of 42 scientific publications and seven books and book chapters. She was a mentor for the preparation of 6 master's theses. She is the head of the chemistry department and the president of the Tuzla Canton Association of Chemists. Selected publications:

1.Almir Šestan,Aida Crnkić, Indira Šestan, Aldina Kesić, Emina Subašić Salkić: Investigation of the heavy metals concentrations ( $\mathrm{Fe}, \mathrm{Mn}, \mathrm{Cu}, \mathrm{Zn}$ AND $\mathrm{Pb}$ ) in the natural system of water/sediment of Spreča river and selected tributaries, Book of Abstracts 5thscientific symposium with international participation "Environmental resources, sustainable development and food production" November 16-17, 2017, Tuzla, Bosnia and Herzegovina. ISSN: 2566-3364.

2.Aldina Kesić, Inela Zaimović, Aida Crnkić, Nadira Ibrišimović Mehmedinović, Almir Šestan, Suad Kunosić: Change of antioxidation activity of honey with influence of different temperatures, Book of Abstracts 5thscientific symposium with international participation "Environmental resources, sustainable development and food production" November 16-17, 2017, Tuzla, Bosnia and Herzegovina. ISSN: 2566-3364

3.Almir Šestan, Edin Hadžimustafić, Indira Šestan, Aldina Kesić, Nadira Ibrišimović Mehmedinović, Benjamin Ćatović.Distribution of Heavy Metals $(\mathrm{Cr}, \mathrm{Cu}, \mathrm{Ni}, \mathrm{Pb}$ and $\mathrm{Zn}$ ) in the Sediment of Some Tributaries and the Part of the River Spreča Flow Presented by the Kriging Geostatistical Method. IJRM International Journal of Research Methodology. Vol.1 Issue: 4, 2018. 4.Aldina Kesić, Bianka Smajlović, Nadira Ibrišimović-Mehmedinović, Zorica Hodžić, Almir Šestan, Jasmina Dedić, Mirza Tupajić. The Content of Total Polyphenols of the Selected Red Wines from the Territory of Tuzla Canton in Correlation with Antioxidant Activity. IJRM International Journal of Research Methodology. Vol.2 Issue: 1, 2019.

5. Stipe Čelan, Zora Pilić, Josipa Karačić, Aldina Kesić, Nadira Ibrišimović Mehmedinović, Anamarija Jurkić.Kemijske i biološke analize meda. Book of Abstract. VI scientific-professional symposium with international participation,Environmental resources, sustainable development and food production“-OPORPH 201914thand 15thNovember 2019, Tuzla, Bosnia and Herzegovina

6.Aldina Kesić, Stipe Celan, Nadira Ibrišimović Mehmedinović, Almir Šestan:Optical activity, total phenolic content and color intensity of nectarian honey and honeydew. European Journal of Food Science and Technology. Vol.8, No.1, pp.12-33, February 2020. Published by ECRTD UK. Print ISSN: 2056-5798, Online ISSN: 2056-5801

7.Aldina Kesić, Inela Zaimović, Nadira Ibrišimović-Mehmedinović, Almir Šestan. The Influence of Thermal Treatment on the Concentration of HMF in Honey. International Journal of Environmental Chemistry2017; 2(1): 1-5 http://www.sciencepublishinggroup.com/j/ijec 10.11648/j.jijec.20170201.11.

8.Aldina Kesić, Inela Zaimović, Nadira Ibrišimović Mehmedinović, Almir Šestan, Suad Kunosić. Bioavailability of total antioxidants from natural food products (honey, cereals, herbs and wines) based on physical-chemical characteristics. Journal of Chemical, Biological and Physical SciencesJCBPS; Section B; May 2018 -July 2018, Vol. 8, No. 3; 521-535,E-ISSN: 2249 -1929 [DOI:10.24214/jcbps.B.8.3.52135.]

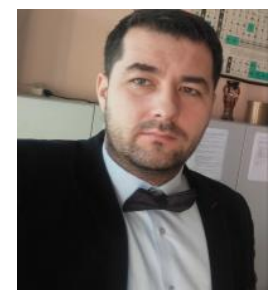

Almir Šestan, is associate professor at Department of Chemistry, Faculty of Natural Sciences and Mathematics, University of Tuzla, Tuzla, Bosnia and Herzegovina. Almir Šestan is author of 28 scientific publications. His research area is in general and inorganic Chemistry. Selected publications:

1. Almir Šestan, Edin Hadžimustafić, Indira Šestan, Aldina Kesić, Nadira

Ibrišimović Mehmedinović, Benjamin Ćatović.Distribution of Heavy Metals ( $\mathrm{Cr}, \mathrm{Cu}, \mathrm{Ni}, \mathrm{Pb}$ and $\mathrm{Zn}$ ) in the Sediment of Some Tributaries and the Part of the River Spreča Flow Presented by the Kriging Geostatistical Method. IJRM International Journal of Research Methodology. Vol.1 Issue: 4, 2018. 2. 4.Aldina Kesić, Bianka Smajlović, Nadira Ibrišimović-Mehmedinović, Zorica Hodžić, Almir Šestan, Jasmina Dedić, Mirza Tupajić. The Content of Total Polyphenols of the Selected Red Wines from the Territory of Tuzla Canton in Correlation with Antioxidant Activity. IJRM International Journal of Research Methodology. Vol.2 Issue: 1, 2019.

3. Kesić, A., Zaimović, I., Ibrišimović-Mehmedinović, N., \& Šestan, A (2017). The Influence of Thermal Treatment on the Concentration of HMF in Honey. International Journal of Environmental Chemistry, 2(1), 1-5. 4. Ibrišimović, M., Ibrišimović-Mehmedinović, N., Dedić, J., Kesić, A., Marić, S., \& Šestan, A. (2017). Effects of various metal and drug agents on excretion of enzyme aspartyl proteinase in Candida albicans and its role in

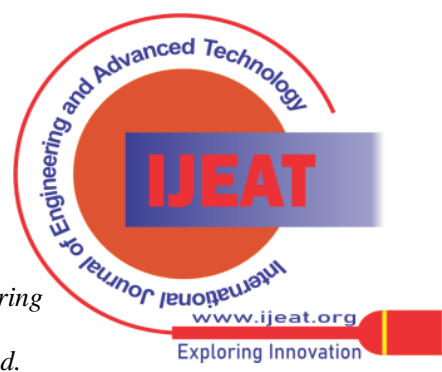
Chemistry, Faculty of Natural Sciences and Mathematics, University of Tuzla, Tuzla, Bosnia and Herzegovina. Her research is in the field of food chemistry, environmental chemistry, and chemistry of medicinal plants.

Aida Crnkić is author of 42 scientific publications.

Selected publications:

1. Kesić, A., Crnkić, A., Hodžić, Z.

(2014). Effects of botanical origin and ageing on HMF content in bee honey. Journal of Scientific Research and Reports, 1057-1066.

(2014). Effects of botanical origin and ageing on HMF content in bee

. Dozic, A., Selimbasic, V., Cipurkovic, A., Crnkic, A., Hodzic, Z., \& ash disposal site Divkovici II. Journal of Life Sciences, 8(5).

, Saletović, M., Crnkić, A., Kesić, A., Mehmedinović, N. I., (Calendula officinalis L.) Grown on Alkaline Soil. American Journal of Applied Chemistry, 4(4), 141-145.

5. Đonlagić, N., Crnkić, A., \& Divković, D. (2012). Determination of Speciation and Bioavailability of Copper in the Lake Modrac With

6. Šestan, A., Crnkić, A., Šestan, I., Kesić, A., \& Dautbašić, A CHEMICAL ANALYSIS OF WATER SAMPLES PUBLIC

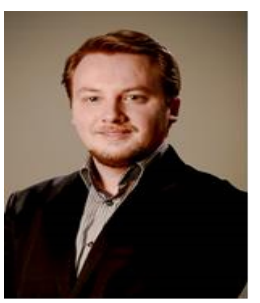

Mirza Ibrišimović, is associate professor at Sarajevo Medical School, at University Sarajevo School of Science and Technology in Sarajevo, Bosnia and Herzegovina, and also works as " cytoscreener-supervisor in Bosnia and Herzegovina. Mirza Ibrišimović is author of 22 scientific publications and four books, including one patent: Patent: Ibrišimović, N., Pittner, F., Ibrišimović, M., Barth, M., Bohrn, U. (2009). Device comprising a polymer layer and a reflecting layer. EP2278300 A1, Europe and USA. Selected publications:

1. Tinjić, S., Abazović, D., Ljubić, D., Vojvodić, D., Božanović, T. Ibrisimović, M., ... \& Ljubić, A. (2021). Influence of autologous in vitro

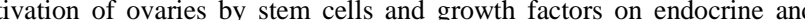
the ovarian insufficiency. International Journal of Fertility and Sterility. Journal of Development Research, 10(04), 34939-34942.

3. Ibrisimovic, M., Markovic, S., \& Tinjic, S.(2020) First-Trimester Placental Morphogenesis as Potential Marker for Early Diagnosis of and Technologa. Vol 9, Issue 9.

4. Tinjić.S.,and Ibrišimović.M. (2019). Introduction of a rutine sperm DNA fragmentation test as a significant help in evaluating male fertiliti potential. Free Radicals on Mobility and DNA Integrity of Human Semin Spermatozoa. International Journal of Engeeniering Research and Technology. Volume 08, Issue 07. 
6. Madacki-Todorović K., Eminović I., Ibrišimović Mehmedinović N., Ibrišimović M. Insulin Acts as Stimulatory Agent in Diabetes-Related Escherichia Coli Pathogenesis. Internationa Journal of Diabetes and Clinical Research. Issue 4, Volume 5, December 2018.

7. Ibrišimović, M., Lion, T., Klein, R. (2013). Combinatorial targeting of 2 different steps in adenoviral DNA replication by herpes simplex virus thymidine kinase and artificial microRNA expression for the inhibition of virus multiplication in the presence of ganciclovir. BMC Biotechnolo, 13:54.

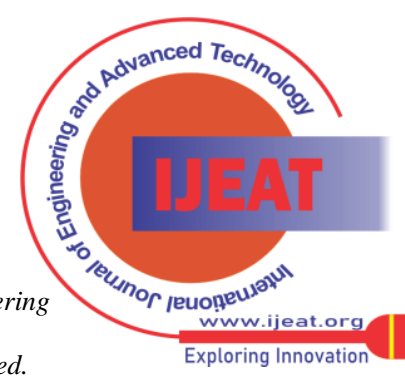

